\title{
Supraglottic Cancer Pathologic TNM Finding v6
}

National Cancer Institute

\section{Source}

National Cancer Institute. Supraglottic Cancer Pathologic TNM Finding v6. NCI

Thesaurus. Code C64668.

A pathologic finding about one or more characteristics of subglottic cancer, following the rules of the TNM AJCC v6 classification system. 